\title{
An important social problem: allergic rhinitis
}

\author{
Önemli bir toplumsal sorun: Alerjik rinit \\ İbrahim Sayın', Cemal Cingi', Turhan San³, Seçkin Ulusoy ${ }^{4}$, Mustafa Acar ${ }^{5}$ \\ ${ }^{1}$ Department of Otorbinolaryngology, Bakırköy Training and Research Hospital, İstanbul, Turkey \\ ${ }^{2}$ Department of Otorhinolaryngology, Faculty of Medicine, Eskişehir Osmangazi University, Eskişehir, Turkey \\ ${ }^{3}$ Department of Otorbinolaryngology, Faculty of Medicine, Istanbul Medeniyet University, Istanbul, Turkey \\ ${ }^{4}$ Department of Otorbinolaryngology, Çorlu Government Hospital, Tekirdağ, Turkey \\ ${ }^{5}$ Department of Otorbinolaryngology, Eskişebir Yunus Emre Government Hospital, Eskişebir, Turkey
}

\begin{abstract}
Allergic rhinitis (AR) affects the individual's quality of life, psychological well being, cognitive functions and sleep quality. Patients often experience annoying symptoms, mood disorders, decreased work productivity and even loss of work. In pediatric patients undiagnosed or untreated/undertreated AR may be related with learning difficulties which may have an important impact on community's present and future life. AR medication, health care utilization, loss of productivity and work is also related with a cost which is also important for patients, their families and society's economic status. All these factors rendered the disease a social aspect. This article aimed to present the social problems generally related to allergic rhinitis.
\end{abstract}

Key words: Allergic rhinitis, comorbidity, burden, socioeconomic, quality of life.

\begin{abstract}
Özet
Alerjik rinit (AR) kişinin yaşam kalitesini, psikolojik iyilik halini, bilişsel işlevlerini ve uyku kalitesini olumsuz etkilemektedir. Hastalar sıklıkla rahatsız edici semptomlar, duygudurum bozuklukları, iş üretkenliğinde azalma hatta iş kaybı yaşarlar. Alerjik rinitlerine tanı konmamış, tedavi edilmemiş veya yetersiz tedavi edilmiş çocuk hastalar toplumun o anki ve ileriki yaşamını önemli oranda etkileyebilen öğrenme zorlukları ile ilişkili olabilir. Alerjik rinit ilaçları, sağlık bakım hizmetlerinin kullanılması, üretkenlik ve iş kaybı hastalar, aileleri ve toplumun ekonomik durumu için önemli bir maliyeti vardır. Tüm bu faktörler hastalığa sosyal bir veçhe kazandırmaktadır. Bu makale alerjik rinitle ilişkili sosyal sorunları genel bir bakış açısıyla sunmayı amaçlamıştır.
\end{abstract}

Anahtar sözcükler: Alerjik rinit, komorbidite, yük, sosyoekonomik, yaşam kalitesi.
Allergic rhinitis (AR) is a globally common disease that affects individuals and community's life in various aspects. ${ }^{[1]}$ It is estimated that AR affects $10 \%$ to $25 \%$ of the total population. Some studies suggest that disease can effect up to $40 \%$ of the pediatric patients. ${ }^{[2]}$ It has an increasing prevalence from infancy to childhood and adoloscence. ${ }^{[3]}$

In general, in most of the countries there is no or little information about the actual total burden of allergic diseases. Gupta et al. had presented the data about the prevalence of symptoms of nasal allergy from 11 European countries. According to the authors, across these 11 European countries the prevalence of symptoms of allergy ranges from $14.1 \%$ to $30.9 \%$ in adults and from $4.5 \%$ to $19.3 \%$ in children. ${ }^{[4]}$

$\mathrm{AR}$ is a chronic disease that requires a long term- treatment. In half of the patients with AR, symptoms are present for more than 4 months and in $20 \%$ of the patients symptoms are present over 9 months.1 "Allergy Living and Learning (ALL)" survey was conducted on 7004 subjects from 10 European countries. Results indicated that patients who received any kind of treatment used their
Correspondence: Cemal Cingi, MD. Department of Otorhinolaryngology, Faculty of Medicine, Eskişehir Osmangazi University, 26020, Eskişehir, Turkey.

e-mail: ccingi@ogu.edu.tr

Received: June 5, 2013; Accepted: July 3, 2013; Published online: November 1, 2013
Online available at:

www.jmedupdates.org doi: $10.2399 /$ jmu. 2013002009 QR code: 
medications for an average of 10.8 years. ${ }^{[5]}$ As a chronic condition, AR significantly affects - social participation and quality of life (QoL). ${ }^{[1]}$

The interaction between any disease and the effects of this disease will be explained by "biopsychosocial model" according to World Health Organisation. ${ }^{[6]}$ This model integrates medical and social aspects of any disease and evaluates the effects of the disease according to its effects on body functions, anatomic structures, activity and social participation. Patients with AR have a significant impairment in their activity and social participation rather than body functions which all indicate $\mathrm{AR}$ as an important social problem. The total burden of AR also is not only related with physical and social functioning but also with its comorbidites and financial aspects. ${ }^{[1]}$

For AR, the evidence suggest that the perception of the disease is different between physicians and patients. ${ }^{[7]}$ Previously physicians tend to evaluate symptoms and focus on parameters which are more objective. But now health professionals are also focusing on quality of life, satisfaction of the patient from medication and other various aspects of the disease.

ALL survey reported that $20 \%$ of the patients had not received any treatment for AR. Previous data also indicated that allergic disorders were underdiagnosed, undertreated and most of the patients did not satisfy with allergy treatment. Unfortunately, diagnosis and treatment are not always undertaken by a specialist who will also explain the reasons of suboptimal management of the disease. ${ }^{[5]}$

AR has a significant effect on patient's daily lives. Higher prevalence, long- lasting symptoms, impairment of sleep, mood and QoL etc. interact with psychological well being which is considerably important for a healthy social life. Higher medical costs related to AR also have socioeconomic consequences. This review aimed to evaluate the social aspects of allergic rhinitis.

\section{Impairment of Quality of Life}

Literature data have demonstrated significant correlations between AR and QoL. Canonica et al. conducted a survey on 3635 patients from the United States and 6 different European countries. ${ }^{[8]}$ Results indicate that symptoms of AR cause significant effects in many domains of patients' lives. For all patients from different countries, sneezing, itchy/watery eyes, nasal congestion and runny nose are the most common complaints for AR. Symptoms are most prominent in the mornings. Fatigue, irritability and sleep disturbances are the most prominent outcomes of symp- toms but vary according to countries. Chivato et al. conducted a telephone based survey called "Allergy, Living and learning (ALL)" on 7004 patients across Europe. ${ }^{[5]}$ In this study $69 \%$ of the patients noted impairment in their daily lives (11\% of them were severe impairment). Daily activities such as exercising, running upstairs, doing housework, visiting friends, spending time in outdoors and sleeping were affected in half of the patients. One third of the patients in this study felt embarrassed or found themselves unattractive due to symptoms. Twenty percent $(20 \%)$ of the patients were not confident taking medications in front of others. Results also indicated that AR has an effect on home life. Patients tend to clean their homes more often, tend to use carpets and avoid contact with pets and refrain from visiting others.

\section{Effects on Sleep}

Up to $88 \%$ of the pediatric and up to $57 \%$ of the adult patients with AR have sleep disturbances. ${ }^{[1]}$ Almost 40 years ago, Cottle acknowledged the importance of healthy nasal function on sleep quality. ${ }^{[9]}$ Sleep impairment has a significant impact on daily lives of patients with AR. Two possible explanations exist for sleep disturbances in AR. Sleep disturbance might be related with nasal obstruction or effects of released inflammatory cytokines on sleep. ${ }^{[10]}$ Previous studies reported a high prevalence of perennial AR in patients with obstructive sleep apnea. ${ }^{[11]}$ Two previous studies on pediatric patients demonstrated AR as a risk factor for habitual snoring. ${ }^{[12,13]}$ Previous reports also showed that intranasal corticosteroid therapy and oral $\mathrm{H} 1$ receptor antagonists (second generation) improved the sleep quality. ${ }^{[9]}$

\section{Effects on Mood and Anxiety}

AR affects the patient emotions and patients felt tired, irritable and embrassed. ${ }^{[1]}$ There is also an interaction between AR and mood disorders. ${ }^{[14]}$ Previous reports indicate that AR was associated with anxiety symptoms, depressive syndromes and even with suicide ${ }^{[15]}$ However this relationship is difficult to prove. The relationship between AR and mood/anxiety disorders might be explained with several suggestions. Both diseases affect the immunity and each one contributes to the other. Both diseases share the same genetic risk. AR will have a negative impact on sleep quality which may inversely affect the psychiatric symptoms. Finally AR has also an impact on cognitive functions which will complicate the physiological well-being. ${ }^{[14]}$ 
The medication will also affect the mood and anxiety. As an example anxiety is a well-known side effect of montelukast therapy. On package label it is noted that besides anxiety montelukast will potentially cause other neuropsychiatric adverse events. ${ }^{[16]}$ Although not clearly demonstrated, FDA also warns about a close relationship between antileukotriene therapy and suicide. ${ }^{[17]}$

There is also a possible relation with AR and neurological conditions such as epilepsy and migraine. In their investigation encompassing 274 patients, Frediani et al. demonstrated a high incidence of allergy in epileptic children and their siblings. ${ }^{[18]}$ In a survey on 133 patients $\mathrm{Ku}$ $M$ et al. reported that migraine had a 14 times higher prevalence in AR patients when compared with patients without migraine. ${ }^{[19]}$ Although not proved, the association between allergen exposure and cerebral dysfunction (if any) should be investigated. ${ }^{[15]}$

\section{Pediatric Problems}

In the pediatric population, AR is the most common chronic allergic disorder. ${ }^{[2]} \mathrm{AR}$ and related comorbidites has a significant impact on children's daily lives. Impairment of sleep, daytime symptoms and fatigue result in limitation of activities in school. Impairment in memory and cognition affects the learning process and school performance. ${ }^{[2]}$ All these factors will lead to sadness, irritability and withdrawal of the children from social activities. Park et al conducted a survey on 780 pediatric patients. Results indicate that patients with AR have higher number of internalizing problems with lower social adaptation. ${ }^{[2]]}$

Children with AR have different problems than children with other allergic disorders like asthma and atopic dermatitis. Children with AR have less functional impairment (e.g. when compared with asthma) however they have a disease that effects physical appearance and attracts the others' attention. This will lead to growth of a withdrawn and a timid child. ${ }^{[21]}$

Engel used a Preference for Activities of Children (PAC) questionnaire to assess the differences in leisure activities between pediatric patients with $\mathrm{AR}$ and healthy patients. ${ }^{[3]}$ This questionnaire included 49 items for recreational, social, active physical, self-improvement/educational and skill based performance domains. Formal and informal activities were also assessed with 14 and 25 items respectively. Except self-improvement and recreational activities all mentioned activities significantly were affected in the AR group. Among them social activities (visiting, going to a party etc.) were the most significantly affected activities.

\section{From the Familial Perspective}

Pediatric patients with $\mathrm{AR}$ are often isolated within the family. ${ }^{[7]}$ Exposure to allergens may limit the participation of the child to family activities. ${ }^{[2]}$ Limitations of activity, above mentioned learning difficulties, and emotional disturbances may affect the parents. Parents will not know the interaction between these problems and AR, thus a communication gap occurs between children and their parents. Parents will experience some degree of anxiety and emotional problems and may reflect these disturbances to the child as becoming overprotective, anxious and even hostile parents. ${ }^{[1]}$ Emin et al. compared family functioning and anxiety parameters between 82 mothers whose children have allergic rhinitis and 70 mothers whose children have no known disease. ${ }^{[2]}$ Mothers whose children have AR have significantly higher anxiety scores than mothers whose children have no disease. Although family assessment scores did not show a significant difference between groups, higher scores were detected in mothers whose children have AR.

\section{Comorbid Diseases}

Several concomitant diseases are associated with AR such as upper respiratory tract infection, sinusitis, otitis media with effusion, nasal polyposis and asthma. Valovirta et al. conducted a survey on 3562 patients from 11 different European countries. ${ }^{[22]}$ They found that asthma (43\%) eczema (32\%), food allergy (29\%) and urticaria (19\%) were the comorbidities of AR. Older patients have more comorbidities than younger ones. Seventy percent of the asthmatic patients thought that AR had a negative impact on the severity of asthma. Percentages of the patients who thought that AR had a negative contributory effect on eczema, food allergy and urticaria were $42 \%, 40 \%$ and $37 \%$, respectively. Schoenwetter et al. reported that AR was the concomitant disease in patients with chronic sinusitis (in $67.5 \%$ of the patients), asthma (21.3\%), otitis media with effusion $(20.8 \%)$ and recurrent nasal polyposis $(2.2 \%) .{ }^{[23]}$ Allergic rhinitis is also a strong risk factor for the development of otitis media and prevalent in patients with otitis media with effusion (OME) ${ }^{[2]}$ In a recent review the prevalence of $\mathrm{AR}$ in patients with chronic or recurrent OME has been reported to vary from $24 \%$ to $89 \%{ }^{[25]}$ This higher comorbidity should alert the treating physician for possible presence of the above mentioned conditions. The effect of one condition on the other should be kept in the mind when treating AR. 


\section{Impairment of Work and Productivity}

Daytime symptoms, sleep disturbances, mood problems may affect the daily work and productivity. ${ }^{[7]}$ Valovirta et al. reported that nearly half of the patients of a total of 3562 participants had experienced difficulty at work. ${ }^{[2]}$ Allergies in America survey was conducted in 2006. In the USA 2500 patients who had been diagnosed as AR and 400 health care providers had participated in this survey. ${ }^{[26]}$ According to this survey $30 \%$ of the patients missed their work because of their allergies. Almost all patients (99\%) thought that their disease had interfered with work. The level of interference was reported as minor $(16 \%$ of the patients), fair ( $28 \%$ of the patients) moderate (35\% of the patients) and extremely (20\% of the patients) disturbing. Reduction on productivity was worsened when symptoms are at worst. Eighty five percent (85\%) of the patients thought that disease had affected their daily lives.

Lamb et al. stated that based on the self-reports of 8267 patients more than half of the employees experienced AR symptoms lasting for 52.5 days. When they experienced symptoms they were unproductive for $2.3 \mathrm{~h}$ per workday. They had lost an average of 3.6 workdays due to AR symptoms. ${ }^{[27]}$

\section{Burden Incurred by Medication}

Patients with AR may use 2 to 4 medications at the same time. Intranasal corticosteroids are the first choice since they are more effective to relief main symptoms such as nasal obstruction, nasal discharge and postnasal drip. ${ }^{[20]}$ However, patients often experience problems related to the efficacy of medications. Although medication may be effective at the beginning of these drug treatments, their efficacy may decrease with time. Patients often dissatisfied with medication and seek for a new allergy medication. Medication may cause unwanted side effects such as drying sensations, drowsiness, bad taste, burning sensation or headaches. ${ }^{[1]}$ Majority of the patients stopped their medication which led to undertreatment of this socially important disease. Use of over-the-counter (OTC) medication is also common in patients with AR. These problematic issues regarding medication use make the overall control of AR more difficult than it be.

\section{Financial Costs}

Allergic rhinitis symptoms are mild and transient in the majority of patients, however its higher incidence will result in increased medical costs. ${ }^{[28]}$ Direct costs include expenditures made for physician visits, laboratory tests, skin prick testing, pharmacological treatment and immunotherapy. Besides direct medical costs, economic burden of the disease is also related to missing work and reduced working capacity. There is also a hidden cost that is associated with the course of comorbid diseases such as sinusitis and asthma. Patients with comorbid AR and asthma have doubled annual medical costs when compared with asthma alone. ${ }^{[2]}$

Goetzel et al. evaluated 375,000 employees and found that $\mathrm{AR}$ is the fifth costly morbid condition due to higher indirect costs. In AR 75\% of the total cost is associated with decreased productivity. ${ }^{[30]}$ In a self reported survey (8267 patient) Lamb et al. reported that the effect of AR on annual productivity is 593 US\$ per employee. This cost is higher than reported for morbidities such as high stress (518 US\$), migraine (277 US\$), depression (273 US\$), hypertension (105 US\$), diabetes (95 US\$) and asthma (85 US\$). ${ }^{[27]}$

Untreated/undertreated patients or patients who do not comply with the drug therapy increase direct and indirect costs. This issue enforces the need for prompt diagnosis and treatment as well as continuous patient education. ${ }^{[29]}$

\section{Conclusion}

Allergic rhinitis is a common disease with gradually increasing prevalence. It will result in significant social burden which also needs to be taken into consideration when preparing AR management guidelines. These guidelines not only need to focus on medications but also on social effects of the disease. A continuous education of family physicians, health professionals, patients and their parents is also needed to lower the actual burden of the disease.

\section{References}

1. Nathan RA. The burden of allergic rhinitis. Allergy Asthma Proc 2007;28:3-9.

2. Emin O, Mustafa S, Nedim S. Psychological stress and family functioning in mothers of children with allergic rhinitis. Int J Pediatr Otorhinolaryngol 2009;73:1795-8.

3. Engel-Yeger B, Engel A, Kessel A. Differences in leisure activities between children with allergic rhinitis and healthy peers. Int J Pediatr Otorhinolaryngol 2010;74:1415-8.

4. Gupta R, Sheikh A, Strachan DP anderson HR. Burden of allergic disease in the UK: secondary analyses of national databases. Clin Exp Allergy 2004;34:520-6.

5. Chivato T, Valovirta E, Dahl R, et al. Allergy, living and learning: diagnosis and treatment of allergic respiratory diseases in Europe. J Investig Allergol Clin Immunol 2012;22:168-79.

6. World Health Organization (WHO). Towards a common language for functioning, disability and health. Geneva: WHO; 2002. p. $1-21$. 
7. Camelo-Nunes IC, Solé D. Allergic rhinitis: indicators of quality of life. J Bras Pneumol 2010;36:124-33.

8. Canonica G. W, Mullol J, Pradalier A, Didier A. Patient perceptions of allergic rhinitis and quality of life: findings from a survey conducted in Europe and the United States. World Allergy Organization Journal 2008;1:138-44.

9. Mullol J, Maurer M, Bousquet J. Sleep and allergic rhinitis. J Investig Allergol Clin Immunol 2008;18:415-9.

10. Sardana N, Craig TJ. Congestion and sleep impairment in allergic rhinitis. Asian Pac J Allergy Immunol 2011;29:297-306.

11. Canova CR, Downs SH, Knoblauch A, Andersson M, Tamm M, Leuppi JD. Increased prevalence of perennial allergic rhinitis in patients with obstructive sleep apnea. Respiration 2004;71:138-43.

12. Li S, Jin X, Yan C, Wu S, Jiang F, Shen X. Habitual snoring in school-aged children: environmental and biological predictors. Respir Res 2010;11:144.

13. Chng SY. Sleep disorders in children: the Singapore perspective. Ann Acad Med Singapore 2008;37:706-9.

14. Sansone RA, Sansone LA. Allergic rhinitis: relationships with anxiety and mood syndromes. Innov Clin Neurosci 2011;8:12-7.

15. Postolache TT, Komarow H, Tonelli LH. Allergy: a risk factor for suicide? Curr Treat Options Neurol 2008;10:363-76.

16. Skillman KL, Stumpf JL. Montelukast-induced anxiety in two pediatric patients. Pharmacotherapy 2011;31:524.

17. Schumock GT, Lee TA, Joo MJ, Valuck RJ, Stayner LT, Gibbons RD. Association between leukotriene-modifying agents and suicide: what is the evidence? Drug Saf 2011;34:533-44.

18. Frediani T, Lucarelli S, Pelliccia A, et al. Allergy and childhood epilepsy: a close relationship? Acta Neurol Scand 2001;104:34952.

19. Ku M, Silverman B, Prifti N, Ying W, Persaud Y, Schneider A. Prevalence of migraine headaches in patients with allergic rhinitis. Ann Allergy Asthma Immunol 2006;97:226-30.
20. Mir E, Panjabi C, Shah A. Impact of allergic rhinitis in school going children. Asia Pac Allergy 2012;2:93-100.

21. Park J, Kim BJ, Kwon JW, et al. Patterns of psychosocial adaptation and allergic disorders in Korean schoolchildren. Int Arch Allergy Immunol 2011;154:249-57.

22. Valovirta E, Myrseth SE, Palkonen S. The voice of the patients: allergic rhinitis is not a trivial disease. Curr Opin Allergy Clin Immunol 2008;8:1-9.

23. Schoenwetter WF, Dupclay L Jr, Appajosyula S, Botteman MF, Pashos CL. Economic impact and quality-of-life burden of allergic rhinitis. Curr Med Res Opin 2004;20:305-17.

24. Sophia A, Isaac R, Rebekah G, Brahmadathan K, Rupa V. Risk factors for otitis media among preschool, rural Indian children. Int J Pediatr Otorhinolaryngol 2010;74:677-83.

25. Lack G, Caulfield H, Penagos M. The link between otitis media with effusion and allergy: a potential role for intranasal corticosteroids. Pediatr Allergy Immunol 2011;22:258-66.

26. Blaiss MS, Meltzer EO, Derebery MJ, Boyle JM. Patient and healthcare-provider perspectives on the burden of allergic rhinitis. Allergy Asthma Proc 2007;28 Suppl 1:S4-10.

27. Lamb CE, Ratner PH, Johnson CE, et al. Economic impact of workplace productivity losses due to allergic rhinitis compared with select medical conditions in the United States from an employer perspective. Curr Med Res Opin 2006;22:1203-10.

28. Hellgren J, Cervin A, Nordling S, Bergman A, Cardell LO. Allergic rhinitis and the common cold -- high cost to society. Allergy 2010;65:776-83.

29. Blaiss MS. Allergic rhinitis: direct and indirect costs. Allergy Asthma Proc 2010;31:375-80.

30. Goetzel RZ, Long SR, Ozminkowski RJ, Hawkins K, Wang S, Lynch $W$. Health, absence, disability and presenteeism cost estimates of certain physical and mental health conditions affecting U.S. employers. J Occup Environ Med 2004;46:398-412.

This is an open access article distributed under the terms of the Creative Commons Attribution-NonCommercial-NoDerivs 3.0 Unported (CC BYNC-ND3.0) Licence (http://creativecommons.org/licenses/by-nc-nd/3.0/) which permits unrestricted noncommercial use, distribution, and reproduction in any medium, provided the original work is properly cited.

Please cite this article as: Sayın İ, Cingi C, San T, Ulusoy S, Acar M. An important social problem: allergic rhinitis. J Med Updates 2013;3(2):91-95. 